\title{
Theoretical Study in Interior Design-Based Online Game Which Raised The Concept of Edutainment in Common Society
}

\author{
${ }^{\mathbf{1}}$ G Hartanti, ${ }^{2}$ I Rachmayanti \\ ${ }^{1,2}$ Interior Design Department, School of Design, Bina Nusantara University, Jakarta, \\ Indonesia \\ ${ }^{1}$ ghartanti@binus.edu, 2ikarachmayanti@binus.ac.id
}

\begin{abstract}
Time flies so fast, as it is characterized by the development of technology in various aspects of life. One of the influences seen in the games sector that raised up in the community is shifting from traditional games to a technology-based games that we know as online gaming. Supported by advanced technology, people's lives are made easier and more affordable in communicating especially in internet access. This is also what makes the development of online games more vibrant in the lives of people, especially the younger generation. Online games have a variety of themes. This study will discuss online games based on interior design. It is expected that with this research, it can be seen the suitability of interior design theories on interior-based online game that raised the concept of edutainment in the common society. By knowing the positive and negative impacts that exist, it is expected in the future that this research can help improving the aspects that need to be considered in interior design based online games. Furthermore, it also can provide a positive impact and reduce the negative impact for its users that will increase the understanding of common society towards general design in overall and interior design theory in particular.
\end{abstract}

Keywords: online game, edutainment, Interior design

\section{INTRODUCTION}

The new era of technology and globalization has influenced some changes to the lifestyle of modern society. The most influential impacts can be seen in the advancement of science and technology, which is also widely used by society as one of their play time activities.

Digital technology is advanced developing which makes a bigger possibility for common people to play online games, and it being used by most of games developer to create interesting games that widely attract youngster and adults. Even now, online games become not only an entertainment purpose, but it evolves to become an educational purpose for its fans.

Various game themes are offered, where one of them is online games that raise the theme of interior design. Online games with interior design themes also have many alternative options that are destined for a specific target market.

This research is aimed to understand the development of an interior design based online games in the market by analyzing interior design theories that applied to interior design based 
online games. It is expected that this research will discover the impact of edutainment concept in interior design based online games to common society.

\section{METHODS}

The research method that will be used in this research is qualitative method by conducting literature study. The literature study conducted to collect data in the form of photos or images of interior design based online games, which are relevant to the research materials. In addition, the method used is the method of observation with direct data collection on online games based on interior design and its users.

\section{RESULT AND DISCUSSIONS}

This section of the researcher tries to compare the two algorithms and find out which algorithm is faster and look for the advantages of each algorithm.

\subsection{Interion Design Principles}

According to [1], there are 7 art and design principles, which are:

1. BALANCE.

Refers to the visual weight of object compositions. It concerns an equality of two particular object in terms of its center of attentions.

2. RHYTHM

A design element that can awakens the deepest emotions or feelings. Rhythm in art and visual designis an object that is marked by a system of repetition on a regular basis. The most common way to get a rhythm is to give a pattern to certain circumstances, which can be recognized and remembered easily. For example, a collection of indiscriminate dots will be difficult to remember its place, in the other hand, points which are grouped in such a way that the repetition of the form is easily recognizable, the aggregate is related to each other and has a pattern.

3. DOMINANCE / EMPHASIS

It created by contrasting color, style, shapes, etc. which will show some focal point of the design. The focal point should be emphasized without distracting the design unity.

4. SCALE

Scale refers to a design element that using a relative size of elements against each other, which can be another way to create dominance and focal point of design.

When elements are designed as superior objects, scale is being used to emphasize its size.

5. PROPORTION

Proportion is a relationship between design objects or parts of a whole. It is necessary to determine proportions using certain context or standard, which a human measurement is a common standard for defining a proportion.

6. HIERARCHY

A good design contains elements that have a red line through each element in order of its significance. The design elements should be recognized and defined starting from most important to the least important.

7. UNITY 
Unity / unity is the integration that means the arrangement of some elements into a unified whole and harmonious. In this case all elements support each other and form a complete unity, not excessive, and no less. How to form unity is by the application of design theme. The dominant idea will form strength in the design. Selected elements are arranged with or to support themes.

\subsection{Online Games}

Refers to IGI Global website, Online Games refer to games that are played over some form of computer network, most often the Internet. Online games can range from simple text-based games to games incorporating complex graphics and virtual worlds populated by many players simultaneously.

\subsection{Game Categories}

\subsubsection{Simulation}

This game is designed to simulate real world activity, such as construction management simulation, vehicle simulation, galaxy war and etc.

\subsubsection{Education}

All types of game that explicitly designed with educational purposes and value, includes board games, card and video games.

\subsubsection{Entertainment}

a. Action - Shooting. This type of games requires reflex speed, hand-eye coordination and time management.

b. Fighting (pertarungan), similar with action genre, it also requires reflex speed, hand-eye coordination and time management, but the main difference is mastering the fighting style and steps, character recognition and timing. The other difference is that this game usually playing versus other players, not only Artificial Intellegence (AI) players as other action games.

c. Adventure, emphasis its story line to provoke user analyzing ability visually, solving a riddle, or summed up its timeline series and characters

d. Role Playing, refers to main characters emphasis which each of the characters can develop their personality, their tools and their roles to what players want, it will be determined by level increasement.

e. Casual games, according to its name, this game is generally is very simple, user friendly and easy to learn. This type of game required low computer specification due to its simplicity. Generally consist of puzzle and simple action theme.

Multiplayer Online, game can be played at the same time with more than 2 players (more often can be played thousands of people at one time). Generally, this type of game required a PC and has RPG theme

\subsection{Design Home}

This research will discuss about Design Home online games application. It is chosen to its quality and achieved a positive high rating and popular among players in 2018. 


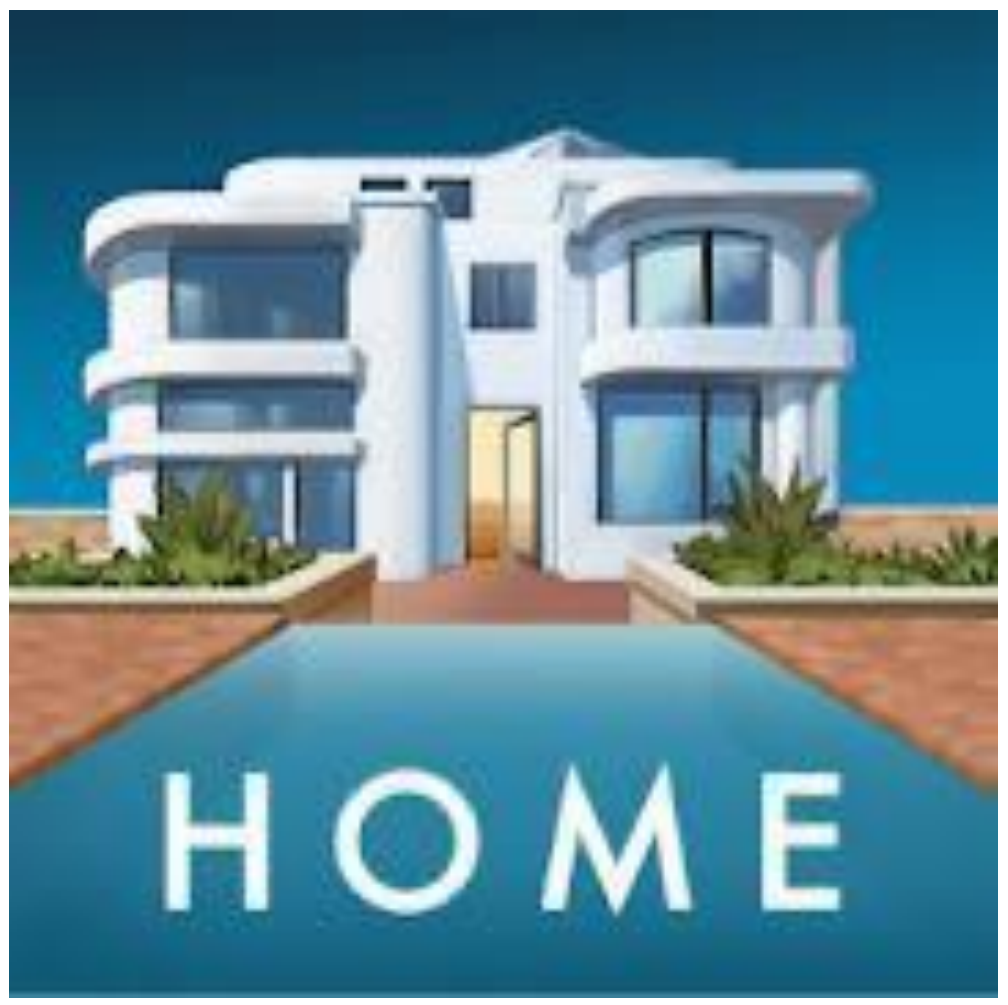

Figure 1. Design Home Logo

According to its official website, Design home is a relaxing, fun game that allows you to live the life of an interior designer. Sharpen your designing skills in daily Design Challenges and style visually stunning three-dimensional spaces with access to real, high-end furniture and decor brands. It's quick, it's fun and you can connect with a vibrant creative community while learning about diverse décor styles - thus improving your design skills and gaining inspiration that you can even apply in your real life.

This game contains comperehensive elements of design that users can create many design posibillity with some creativity, for example, there are various choices of furniture and other design element that has a modern and up to date database which makes this game become one of few close-to-reality interior design based game.
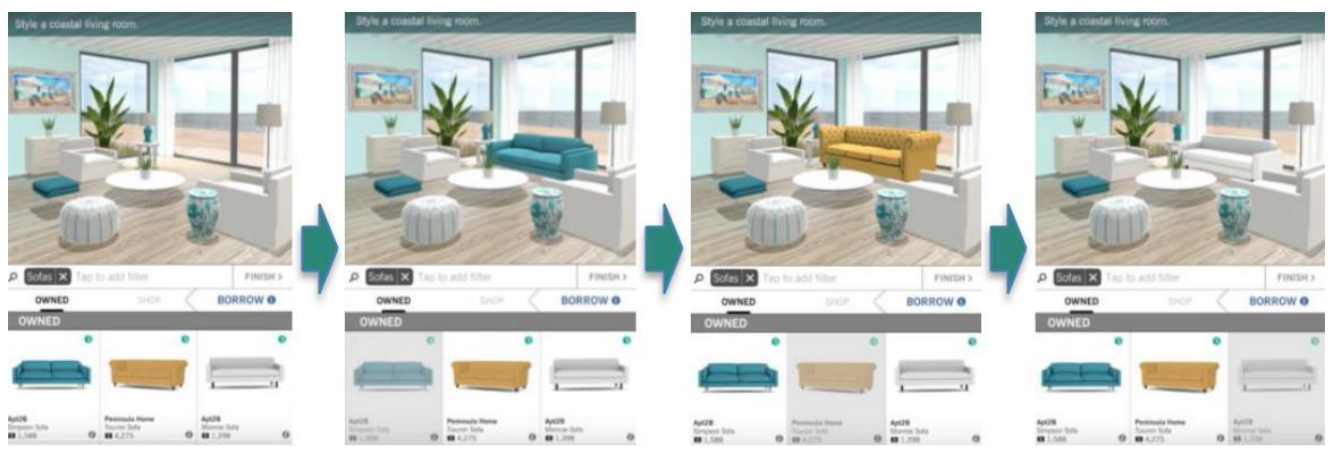

Figure 2. Sofa Selection in Design Home Online Games Application. 


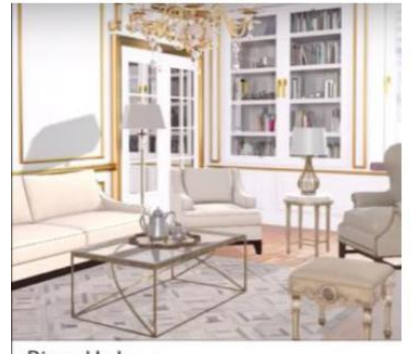

Dipped In Luxe

$\star 4.14$

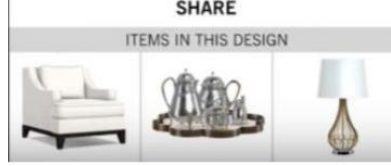

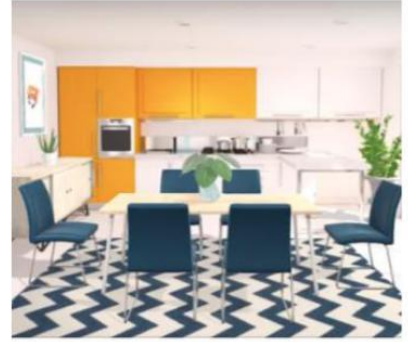

Simply Modern

$\star 4.14$
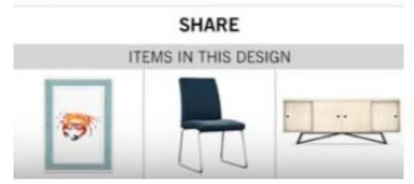

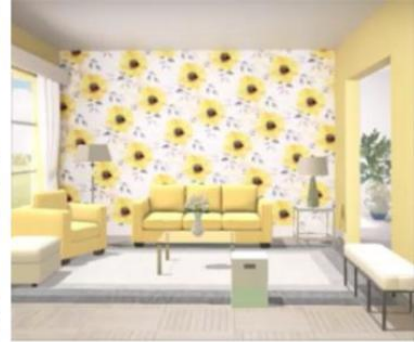

Field Of Yellow

$\star 4.14$

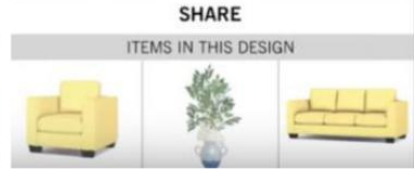

Figure 3. Style and Theme Selection in Design Home Online Games Application.

After designing a room or an ambience, user can freely upload and share their design to social media such as Facebook, or sign up for a vote competition to gain points.

\subsection{Analysis with Goal Grid}

This game is analysed with Goal Grid method which used four components of analysis, achieve, avoid, preserve and eliminate. These four components will determined this advantage and disadvantage, and what to be improved and what to be avoided. It will help the creator to improve the game and also the user to educate them with game that has more realistic interior design ambience following a proper design principles. 


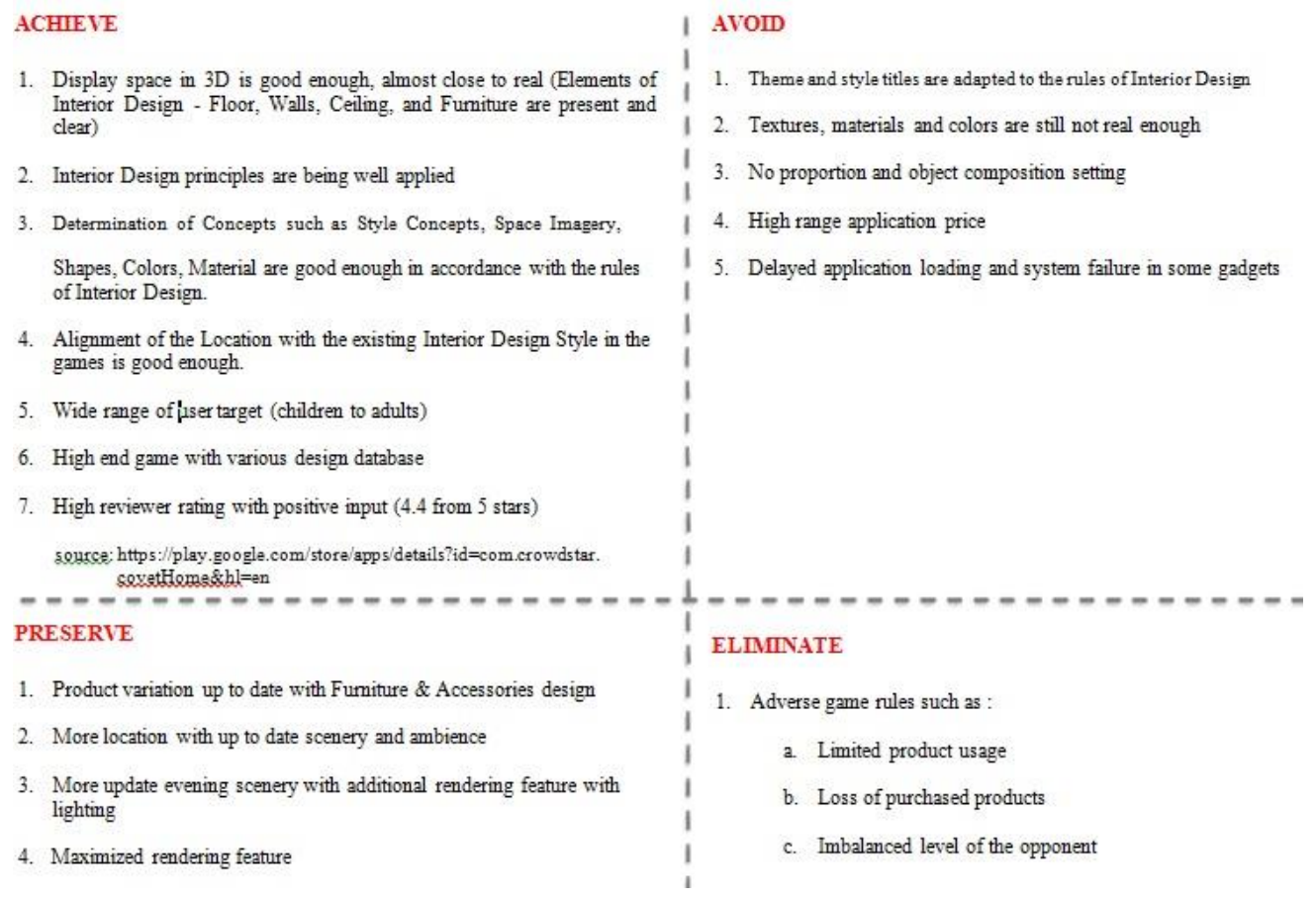

Figure 4. Goal Grid Analysis

\section{CONCLUSION}

This study provides an overview of the lifestyle changes that marked the shift of traditional games to game-based technology that is in trend with online games term among modern society. This study focuses on online games based on Interior Design that aims to find out the suitability of interior design science on interior-based online game which can be an edutainment device to introduce interior design subject and principles to general society.

Case Study taken in this research is an interior design based online game application "Design Home" where after analyzed by using Goal Grid method with 4 parts (reach, avoid, preserve, and eliminate); it appears that this online game 'Home Design' already has a good achievement marked by its interior space 3D rendering is close to realism, the congruity to the principles and rules of interior design, and wide variations of furniture products are more than enough to attract players.

In terms of game improvement, it should be noted to some aspects both in terms of visual and technical. It is expected that with the improvement of the game product variation update, well managed systems and user feedback concern, the existence of interior-based online game "Design Home" can continue to be in demand by its users.

It is expected that online games especially an interior design based online game not only become an entertainment product, but it also can educate its user with general knowledge of interior design, so they can be aware with some basic design principles through this game. 
So that with a good example, this game can be used as a benchmark for other similar online games to become a game application with a positive impact and reduce negative impacts for users and increase their knowledge of general design and interior design in particular.

\section{REFERENCES}

[1] W. Lidwell, K. Holden, and J. Butler, Universal Principles of Design, Revised and Update: 125 Ways to Enhance Usability, Influence Perception, Increase Appeal, Make Better Design Decisions, and Teach Through Design. New England: Rockport, 2010.

[2] Arnold J D 1980 The Art of Decision Making (New York: AMACOM)

[3] Barnard C A 1938 The Functions of the Executive (Cambridge: Harvard university Press)

[4] Nickols F 2003 The Goals Grid: A Tool for Clarifying Goals \& Objectives

[5] Ching F D 1996 Ilustrasi Desain Interior (Jakarta: Erlangga)

[6] KBBI. (n.d). (Badan Pengembangan dan Pembinaan Bahasa, Kemdikbud (Pusat Bahasa)) Retrieved from Kamus Besar Bahasa Indonesia online version https://kbbi.web.id/

[7] Suptandar J P 1999 Desain Interior: Pengantar Merancang Interior Untuk Mahasiswa Desain dan Arsitek (Jakarta: Djambatan)

[8] Zikri F 2013 Aplikasi game 3D First Person Shooter (FPS) survive from death Online http://elib.unikom.ac.id/files/disk1/622/jbptunikompp-gdl-fajarzikri-31059-10unikom_f-i.pdf

[9] Krismanadil 20167 Prinsip Dasar Desain Arsitektur Online http://krismanadil.web.ugm.ac.id/7-prinsip-dasar-desain-arsitektur/

[10] Ridoi M 2018 Cara Mudah Membuat Game Edukasi Dengan Construct 2 (Malang: Sasugagame)

[11] Christianto D 2017 Ini 8 Jenis Genre Game dan Sub Genre-nya Online https://www.inigame.id

[12] IGI Global What is Online Games Online https://www.igiglobal.com/dictionary/online-games/20978 